Discovering Exile 

Stanford Studies in Jewish History and Gulture edited by Aron Rodrigue and Steven J. Zipperstein 



\section{Discovering Exile}

Tiddish and Jewish American Culture during the Holocaust

Anita Norich 
Stanford University Press

Stanford, California

(C) 2007 by the Board of Trustees of the

Leland Stanford Junior University.

All rights reserved.

Published with the assistance of the University of Michigan's Office of the Vice President for Research and the College of Literature, Science, and the Arts.

No part of this book may be reproduced or transmitted in any form or by any means, electronic or mechanical, including photocopying and recording, or in any information storage or retrieval system without the prior written permission of Stanford University Press.

Library of Congress Cataloging-in-Publication Data

Norich, Anita, I952-

Discovering exile : Yiddish and Jewish American culture during the Holocaust / Anita Norich.

p. $\mathrm{cm}$.

Includes bibliographical references and index.

ISBN 978-0-8047-5690-7 (cloth : alk. paper)

I. Yiddish literature-United States-History and criticism.

2. Yiddish literature - 2oth century-History and criticism.

3. Holocaust, Jewish (1939-1945)-Influence. 4. Jews-United

States-Intellectual life. 5. Asch, Sholem, I880-1957. 6. Glatstein, Jacob, I896-I97I. 7. Authors, Yiddish-United States. I. Title.

PJ5I5I.I.N67 2007

839'.1309973-dc22

2007001775

Typeset by Classic Typography in I0.5/14 Galliard 


\section{צום אייביקן אָנדענק פَון טאַטן \\ יצחק נאָריך ז"ל}

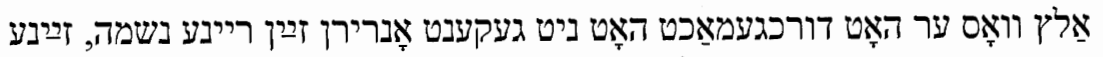

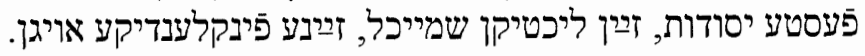

This Book Is Lovingly Dedicated to My Father,

Isaac Norich,

Who Lived a Life of Quiet Inspiration. 
